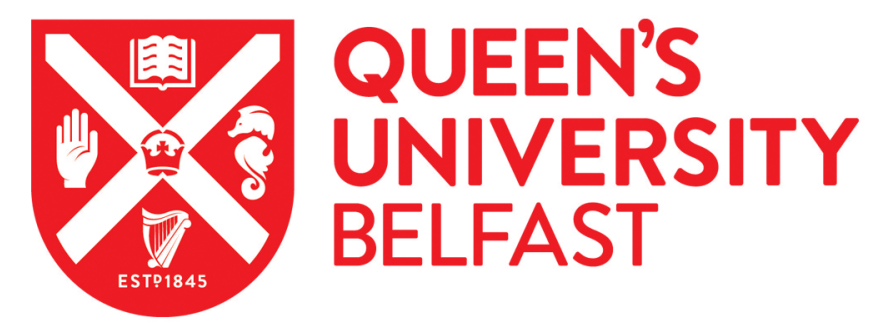

\title{
The shifting boundaries of global staffing: integrating global talent management, alternative forms of international assignments and non- employees into the discussion
}

Collings, D. G., \& Isichei, M. (2017). The shifting boundaries of global staffing: integrating global talent management, alternative forms of international assignments and non-employees into the discussion. International Journal of Human Resource Management, 29(1), 165.

https://doi.org/10.1080/09585192.2017.1380064

\section{Published in:}

International Journal of Human Resource Management

\section{Document Version:}

Peer reviewed version

Queen's University Belfast - Research Portal:

Link to publication record in Queen's University Belfast Research Portal

\author{
Publisher rights \\ (c) 2017 Informa UK Limited, trading as Taylor \& Francis Group. This work is made available online in accordance with the publisher's \\ policies. Please refer to any applicable terms of use of the publisher.
}

\section{General rights}

Copyright for the publications made accessible via the Queen's University Belfast Research Portal is retained by the author(s) and / or other copyright owners and it is a condition of accessing these publications that users recognise and abide by the legal requirements associated with these rights.

Take down policy

The Research Portal is Queen's institutional repository that provides access to Queen's research output. Every effort has been made to ensure that content in the Research Portal does not infringe any person's rights, or applicable UK laws. If you discover content in the Research Portal that you believe breaches copyright or violates any law, please contact openaccess@qub.ac.uk. 
The Shifting Boundaries of Global Staffing: Integrating global talent management, alternative forms of international assignments and non-employees into the discussion.

\author{
David G. Collings \& Michael Isichei
}

\begin{abstract}
Global staffing has been a key theme in research in international human resource management (IHRM) for a number of decades. Our review confirms that it continues to be an important contemporary area of research in IHRM. In the current paper, we review three key contemporary issues in global staffing research, namely, the emergence of global talent management and potentially a more strategic approach to global mobility, specifically changing patterns of global mobility, and the emergence of the non-employees as key alternatives in the global staffing literature. The paper also charts a future research agenda in each of these areas.
\end{abstract}




\section{INTRODUCTION}

Global staffing, defined as "the critical issues faced by multinational corporations with regard to the employment of home, host and third country nationals to fill key positions in their headquarter and subsidiary operations" (Scullion and Collings, 2006:3) remains one of the key areas of research in international human resource management (IHRM). The centrality of effective global staffing arrangements to the ability of multinational enterprises (MNEs) to deliver on their strategic objectives is widely recognised (Cascio \& Boudreau, 2016; Collings, Scullion \& Dowling, 2009; Schuler, Dowling and DeCieri, 1993). Global staffing is central to the MNE's ability to achieve learning, innovation and corporate integration which are in turn identified as the objectives of strategic IHRM systems (Gong, 2003; Schuler et al, 1993). Writing almost a decade ago Collings et al (2009) noted that the literature on global staffing had been dominated by research on expatriation, particularly of parent country nationals (PCNs)- individuals from the home country of the MNE sent on assignment to subsidiary locations, (for recent reviews see Baruch, Altman and Tung, 2016; Caligiuri and Bonache, 2016; Kraimer, Bolino and Mead, 2016) and that third country nationals (TCNs) and other staffing options were poorly understood. Indeed, a recent review of research on IHRM published in one leading journal pointed to a peak in research on expatriation in the period 2005-2009 reflecting this trend (Cascio \& Boudreau, 2016). However, arguably the literature base has expanded in recent years and we can see a broader research agenda emerging in global staffing.

The objective of the current paper is to identify the key contemporary trends in the global staffing literature and to chart a future course for research in this area. This is significant owing to the long-established recognition of the importance of global staffing to the strategic objectives of the MNE. 
However, at the time of writing there are significant challenges to the movement of people across borders which require some reflection on the trajectory of global people flows. Populist politics with the BREXIT vote in the United Kingdom and Donald Trump's election in the US were inter alia premised on a nationalist political narrative that challenged the position of migrants including migrant labour in those countries. The so called "travel ban" that was introduced by President Trump and the re-evaluation of the $\mathrm{H}-1 \mathrm{~B}$ visa programme threaten the ability of the US to attract skilled talent into the country (Mahmud, 2017; You et al, 2017). Indeed, Microsoft has already opened a satellite office in Vancouver, Canada to mitigate the challenges in accessing key talent created by these changes, with many other tech companies reported to be considering their options (Dixon, 2017). Similarly, the uncertainty created in the UK by the status of EU workers there in light of the BREXIT vote is beginning to impact on the availability of talent in that country (Allen, 2017). These, and other wider political trends, may constrain the ability of MNEs to relocate PCN and TCN talent into these markets and the availability on non-local talent in local labour markets. The wider impact remains to be seen however.

Similarly, the nature of work has altered significantly. In this regard, Morgan (2014) identifies a number of key trends which will shape the nature of work in the future. These include changes to how we collaborate and share information such as the shift to the cloud. The emergence of collaboration platforms which have important implications for connecting and engaging people anytime, anywhere and on any device. Big data also facilitates better decision making, although progress here has been slower than one might have expected (see Marler and Boudreau, 2017). Increasing the mobility of work and labour. These trends have already seen employment become much less location dependent. This has promoted remote working, where employees can work and collaborate regardless of their location, and has also provided support for the perspective that talent does not need to be local. Indeed, talent markets now operate on an increasingly global 
basis and technology facilitates global collaboration. Inter alia these trends have been reflected in a rise in off-shoring of work, an increase in white-collar work, the emergence of more contingent work arrangements such as contracting, freelancing and the wider gig-economy, and an increase in project based work (Barley, Becky and Milliken, 2017).

Finally, the use of international assignments in organisation and the conditions under which individuals accept or decline international roles have altered significantly over recent years (Bolino et al, 2017; Collings et al, 2007). This has significant implications for MNEs in terms of the availability and willingness of individuals to undertake international roles. It has thus forced MNEs to re-evaluate their approaches to global staffing and consider a wider range of staffing options to deliver on the strategic intent of the MNE.

Our review is positioned in this dynamic context which significantly influence how organisations approach their global staffing challenges. Based on these challenges, and the staffing issues which they precipitate, in the current paper, we review three key contemporary issues in global staffing research, namely, the emergence of global talent management and potentially a more strategic approach to global mobility, specifically changing patterns of global mobility, and the emergence of the non-employees as key alternatives in the global staffing literature.

\section{Global Mobility and Global Talent Management}

Global talent management (GTM) has emerged, over the past decade, as a key theme in international human resource management (IHRM) research and practice (see Al Ariss et al, 2014; Scullion et al, 2010; Stahl et al, 2012; Tariq \& Schuler, 2010). It is regarded as central in delivering on the MNE's strategic objectives. A key advantage which MNEs have over domestic firms is the ability to source talent beyond national borders. This is a means of navigating the 
challenges created by issues such as the challenge to $\mathrm{H}-1 \mathrm{~B}$ visas in the US identified above. Global talent strategies are also impacted by individual's willingness to relocate internationally. Indeed, the integration between global mobility and global talent is increasingly important in managing the supply and demand of globally mobile professionals (Caligiuri and Bonache, 2016). While there remains some debate as to the precise definition of global talent management, we adopt Mellahi and Collings' (2010: 143) definition which posts that GTM involves: (1) the systematic identification of pivotal positions that differentially contribute to the organization's sustainable competitive advantage on a global scale; (2) the development of a talent pool of highpotential and high-performing incumbents who reflect the global scope of the MNE to fill these roles; and (3) the development of a differentiated human resource architecture to fill them with the best available incumbents to ensure their continued commitment to the MNE.

Central to this definition is the idea of pivotal positions which Boudreau and colleagues argue are central to global talent management and require further clarification (see Cascio and Boudreau, 2016). Consistent with Boudreau's work we view pivotal positions as defined by their centrality to organisational strategy combined with the potential of a change in the quantity or quality of people in those roles to impact disproportionately on the delivery of the MNE's strategic objectives. Understanding these pivotal roles and their distribution across the MNE's global network is thus the key point of departure in GTM. Global talent pools recognize the importance of talent across the MNE network and beyond the traditional PCN elites who dominated discussions on global staffing. Finally, the notion of differentiated HR architecture (Lepak and Snell, 1999) facilitates the deployment and retention of the MNE's high performers and high potential employees to deliver on the MNE's strategic intent, and helps to ensure the ongoing commitment of those highperforming and high-potential employees to the organization (Mellahi and Collings, 2010). While a detailed discussion of the distinctions of high performance and high potential are beyond the scope of the current paper (see Nijs et al, 2014 ; O’Boyle and Kroska, 2017; Silzer and Boreman, 
2017 for a fuller discussion), evaluations of performance are generally based on job or task performance in this regard. Performance is generally a function of how an individual performs relative to his or her peers or a similar referent group. Potential is generally an estimate of an individual's capacity for growth and development within the organisation. However, in many organisations the consideration of potential is often limited to perceptions of leadership potential as opposed to potential to grow within the one's specialist area.

This is certainly a new area of academic research in global staffing but one which has the potential to significantly impact on the future of the area in theory and practice. One key question that emerges in this debate is the skill set required of global mobility professionals to deliver on the strategic agenda (Caligiuri and Bonache, 2016). Indeed, the evidence available suggests that currently there is a mismatch between the required skills and those of the global mobility function (Cerdin \& Brewster, 2014; Collings, 2014; Farndale et al, 2014). For example, the 2015 RES Forum Annual Report, confirmed that GM professionals consider their roles to be more operations focused than people focused, with $79 \%$ of respondents considered experts on due diligence compared to only $7 \%$ enacting the role of global talent manager (Dickmann, 2015). Further, insights from the same report suggest that top management priorities for GM have not pointed in the direction of greater integration with GTM. The roles of strategic advisor (56\%) and expert on due diligence (42\%) were found to be valued more by top management compared to the roles of global talent manager (15\%) and global people effectiveness expert (9\%). A recent global mobility report notes that "more than ever mobility must be ready to play a central and more "mindful" role in a company's global talent management strategy' (Brookfield Global Relocation Services, 2015: 4). Thus, while it appears that professionals recognize the value of greater integration between GM and GTM arguably the function lacks the resources and capabilities to deliver on that agenda. Academic research should focus on understanding what the key required capabilities are and 
how the value of global mobility can be better captured (See Doherty and Dickmann, 2012; McNulty, DeCeiri and Hutchings, 2009).

Much of the academic discussion on the role of GTM in global staffing has focused on the macro or organizational level. However, in examining the question from an individual level there are a number of areas which appear ripe for further study. From the individual assignee perspective, Collings and Isichei (2017) have argued that, considering GTM within the context of the preassignment, assignment, and post-assignment stages of the IA cycle could help to develop the integration between GM and GTM. During the pre-assignment stage selecting suitably skilled and qualified individuals for assignments, with the motivation for international work, is a main concern for MNEs. Empirical research confirms that the selection of international assignees has traditionally followed an informal process dependent on personal networks (Harris \& Brewster, 1999). A more strategic approach to assignee selection which is linked to organizational strategy and individual career plans would allow for greater integration between GM and GTM (Cerdin \& Brewster, 2014; Collings, 2014). Potential should also be considered in addition to performance in selecting these individuals where there is a developmental focus for the roles (Borman and Silzer, 2017). In addition, the implementation of a global talent-pool strategy (Collings, 2014) has the potential to link assignee selection to GTM, by ensuring that all high potential employees across an organization's global network are considered for international assignments as part of a career development process. While some have considered the role of the corporate HR function in this regard (Farndale et al, 2010; Sparrow, 2007; Scullion and Starkey, 2000), it remains an interesting area for further study and ultimately a balanced understanding of organisaional and individual priorities seems an important means of progressing our understating of the area (Farndale et al 2014). The imbalanced consideration of assignee objectives for international assignments can result in perceived breach of the psychological contract (see Haslberger \& 
Brewster, 2009; McNulty \& DeCieri, 2016) and have wider implications for the career development of high potential employees and their commitment to their organization.

Once deployed, global mobility plays an important role in the development of high potential employees. Within the context of GTM, development is often a central objective of IAs (Collings, 2014). Therefore during an assignment a primary concern for the GTM function is the developmental experience attained by high potential employees. Defining GTM as we do emphasizes the movement of talent across a MNE's global network through the use of IAs but also the importance of local talent in subsidiary operations (McDonnell, Scullion, \& Lavelle, 2013; Shen \& Hall, 2009). International experience can prove to be quite telling when members of an organization's talent pool move into senior management positions. Research indicates that the international experience of senior MNE managers can influence the strategic direction of their organizations and firm performance (Carpenter \& Fredrickson, 2001; Carpenter, Sanders \& Gregersen, 2001). However, worryingly recent practitioner evidence suggests a decline in the number of global CEOs with international experience (only $24 \%$ of new CEOs in this study) (PWC, 2017). While a complete review of the developmental impact of global mobility is beyond the scope of the current paper (see Bird and Mendenhall; 2016; Caliguiri and Bonache, 2016; Caligiuri and Dragoni, 2015) the value of international experience from a developmental perspective is widely accepted (Bird and Mendenhall, 2016; Caligiuri and Bonache, 2016). However, it is not clear that organizations actually integrate development opportunities into career paths for those identified as talent (Collings, 2014). This is reflected in for example the continuing high levels of attrition of individuals on their repatriation from international assignments to which we now turn.

The post-assignment stage is concerned with the repatriation of international assignees. This stage has often proven to be problematic for assignees and MNEs alike. In some instances, assignees find the experience of repatriation to be equally, and at times more, difficult than their 
initial transition abroad (Adler, 1981; Harvey, 1989). The difficulties experienced by returning assignees are reflected in post-assignment attrition rates of between 15\% and 30\% (Black \& Gregersen, 1999; Brookfield Global Relocation Services, 2015; Doherty \& Dickmann, 2012; Suutari \& Brewster, 2001). Returning assignees often experience frustration related to the MNE's failure to link their IA experiences to their career development (Collings, 2014; Lazarova, 2015; Pate \& Scullion, 2009). Somewhat ironically for many individuals the failure to acknowledge the developmental benefit of the assignment (Caligiuri and Bonache, 2016) stands in stark contrast to the premised developmental objective of the assignment in the first place. Thus, the challenges of repatriation in the context of GTM remain prevalent (see Lazarova and Cerdin, 2007). One potential way forward is to view repatriation not as an end-point in the IA cycle, but rather as an intermediate stage which is linked to broader career and development issues (e.g., Doherty et al. 2008). This perspective of repatriation can help improve the integration between GM and GTM. The perspective shifts the focus away from the mere reintegration of an assignee into their home office, towards greater consideration of how the experience gained while on assignment can feed into the next stage of an assignee's career development. The perspective helps to improve the integration between GM and GTM by ensuring that MNEs are intentional about the development of employees beyond IAs.

The increasing consideration of global staffing in the context of global talent management represents an important contemporary issue in global staffing research and there appears significant potential for further study in this area. We now consider the second key theme in our review of global staffing literature, the increasing emphasis on alternative forms of international assignments. 


\section{Alternative Forms of International Assignments}

The second key emerging trend in global staffing research is alternative forms of international assignments. This stands in contrast to the central focus on traditional longer term assignments, typically three to five years in duration and involving the relocation of an assignee and their family, which dominated global staffing research in the past (Baruch et al, 2013; Dowling et al., 2008). Over the past decade academic literature has begun to explore these alternatives to the traditional long-term IA (Bozkurt \& Mohr, 2011; Mäkelä, Saarenpää \& McNulty, 2017; Mayerhofer, Hartmann, Michelitsch-Riedl, \& Kollinger, 2004; Meyskens et al., 2009; Pate \& Scullion, 2016; Scullion, Collings, \& Gunnigle, 2007; Tahvanainen, Welch, \& Worm, 2005). This emerging stream of academic literature responds to changes in global staffing practice. In particular, inter alia, pressures to reduce costs, demand and supply imbalances in globally mobile talent, and changing attitudes towards careers and willingness to relocate abroad as noted above, combined with the increasing challenges to relocating staff to key developed economies such as the US and UK, have encouraged increased use of non-standard IAs in MNEs. The use of these alternatives has been facilitated by the technological, travel and other advances outlined earlier.

While clearly the traditional long-term IA remains an important staffing mechanism in MNEs, it has become less dominant as MNEs recognize the value of less lengthy alternatives. In one recent survey over one third of respondents indicated that they expect the number of traditional assignments to be reduced over the next 5 years, a trend that has been evident for a number of years (Santa Fe Relocation Services, 2017). The same survey revealed that the increasing use of alternatives to the traditional long-term IA, such as, short-term assignments, international business travellers (IBT), and commuter assignments represents the biggest expected change in

global mobility over the same period. Thus, the topography of global mobility has altered significantly over the past decade or so. However, how these trends play out over the coming 
years given the changing political landscape and approaches towards migration mobility will be a key question also.

Over a decade ago Collings, Scullion, and Morley (2007) reviewed this changing topography of global mobility and summarised the then emerging alternatives to the traditional long-term assignment. In revisiting their overview, we review the literature on these alternatives to consider how our understanding of them has evolved over the last decade. We focus specifically on shortterm assignments, international business travelers, commuter and rotational assignmentsi. Table one provides a summary overview of the key trends in this regard.

TAKE IN TABLE 1 APPROXIMATELY HERE

\section{Short-term International Assignments}

Short-term international assignments are defined as temporary internal transfers to foreign subsidiaries which are between one and twelve months in duration (Collings, Scullion and Morley, 2007). They generally do not involve the relocation of the assignee's family and benefits and salary often remain in the home country (Tahvanainen et al., 2005). Short-term assignments are considered the most popular alternative to the traditional IA (KPMG, 2015a; PWC, 2014; Santa Fe Relocation Services, 2016; Tahvanainen et al., 2005).

Somewhat surprisingly, given its importance in practice, there has not been a surge in academic research in this area. Reflective of this, in their comprehensive review of the expatriation literature Caligiuri and Bonache (2016) did not explicitly discuss any research findings on this topic. The 
research that is available suggests that short-term assignments can offer positive professional experiences (Crowley-Henry \& Heaslip, 2014). In one of the only studies that looks at the impacts of short-term IAs for the organisation, Bozkurt and Mohr (2011) pointed to the potential of such assignments to build social capital in the MNE. This was traced to the fact that these assignments brought together assignees from around the MNE, often to work on specific projects, expanding interaction beyond locals and increasing the number of interaction partners in the MNE network. They were also more commonly utilised for subsidiary employees than HQ employees. These assignments were particularly valuable for younger employees (who may lack the capability for more critical appointments) and also for those whose family circumstances prevented them taking longer roles. However, the separation which short-term assignments impose on assignees and their families can also result in negative experiences both during and after an assignment. Starr \& Currie (2009) demonstrated that the absence of the support of a spouse can be difficult for assignees to handle during such assignments. Further, personal changes experienced by an assignee while on assignment (Harvey \& Novicevic, 2006; Osland, 1995) can affect their relationship with their spouse upon their return (Starr \& Currie, 2009). As too can feelings of coercion to accept the assignment in the first instance (Copeland, 2009). However, a sense of agreement, (i.e. "we're in this together"), may buffer the impact of separation on relationships (Copeland, 2009: 30). Thus, consistent with the broader expatriation literature, research on shortterm IAs draws attention to the importance of spousal and family support in offsetting work-family conflict (Mäkelä, Känsälä \& Suutari, 2011).

However, given that the work-family interface is affected in different ways owing to the fact that the family generally does not relocate with the assignee (Shaffer et al, 2012) this is a question which requires further empirical study. A second assumption of short-term international assignments is that owing to their shorter duration challenges around adjustment and repatriation will be lessened. While we have limited empirical research on this question, Star's (2009: 297) 
study on the repatriation of short-term assignees concluded "short-term assignments may to a certain degree avoid some of the problems traditionally associated with long-term assignments, but also create new ones". For example, her study found that some individuals on short-term assignments had similar expectations to those of longer term assignees around upward career

mobility on completion of the assignment. This work suggested that repatriation was managed on an ad-hoc basis for many short-term assignees leading to frustration. While practitioner data point to the increased development of specific policies for short-term assignees, it appears that many of the same issues that emerge in traditional long-term assignments endure.

\section{International Business Travelers}

IBTs are employees who are required, as part of their role, to make frequent international visits to foreign markets, units, projects and the like (Welch, Welch \& Worm, 2007). They are open to a wide cohort of MNE employees. Compared to other alternative forms of IAs, international business travel is less structured. IBTs are often deployed to meet organizational needs that evolve on an on-going basis (e.g. negotiations, conferences, meetings with stakeholders). Individuals therefore often embark on international business trips with little prior notice. Indeed, it has been argued that decisions about when to travel for these individuals are often at the mercy of their line manager (Mayrhofer et al, 2004; Shaffer et al, 2012). International business travelers (IBTs) are a steadily growing alternative to the traditional IA. Recent industry research, indicates that up to $64 \%$ of MNEs formally define IBTs (Santa Fe Relocation Services, 2017). There has been some instructive research on IBTs. Given the challenges of IBT, Phillips et al (2014) provide some interesting insights into how shaping the recruitment message to communicate the requirement for frequent travel can attract individuals with a desire to travel to particular roles. Their work is informative in targeting individuals with higher levels of willingness to work internationally in recruitment to increase the pool willing to undertake such travel. 
Business travel has been identified as an effective means of building social capital within the MNE (Bozkurt \& Mohr, 2011). Specifically, IBT was identified as key in developing cross-unit social ties and sustaining social networks in MNEs. Bozkurt and Mohr (2011: 150) argue based on their empirical study "business travel offer[s] continuity to social ties established via all the different forms of social mobility, but among all the different forms it emerged as the one that allowed the greatest discretion to individual actors to arrange in ways that consolidated their existing ties". Thus, IBT represents a key form of organizational glue- an underlying process used to stick two parts of the organization together- which is central to organizational effectiveness (Evans, Pucik \& Barsoux, 2002: 306).

The broadest body of research on IBTs has focused on stress and conflict issues. Indeed, one of the key challenges of IBT is high levels of stress, which contributes to negative physical and emotional outcomes for those concerned (Welch, Welch \& Worm, 2007). A recent study of 232 IBTs (Mäkelä and Kinnunen, 2016) found that workload and pressure experienced during the course of IBT contributes to job exhaustion, which can subsequently have negative implications for a IBT's health. The frequent transitions between domestic and multiple international units, combined with frequent transitions between home and work lead to significant role conflict for IBTs (Welch et al, 2007). IBT can however also have positive impacts on affective states. For instance, in a study of 275 IBTs and their spouses, Westman, Etzion, and Chen (2009) found that IBT was positively related to work engagement and specifically vigour. Furthermore, the experiences of IBTs positively crossed over to their spouses, in that the vigour that they experienced was transmitted to their spouses. The finding indicates that the positive affective state of an assignee can crossover (Westman and Etzion, 1995) to their spouse. Like short-term assignments, IBT can also impact an assignee's family life. For IBTs who are parents, lengthier business travel can increase work-family conflict (Mäkelä et al., 2015). 


\section{Commuter and Rotational Assignments}

Commuter assignments involve an assignee travelling from their home location to take up a post in a foreign location on a weekly or bi-weekly basis (Mayrhofer, Reichel, \& Sparrow, 2012). Employees on such assignments have work responsibilities in a home and host country, but maintain their residence in their home country, returning at frequent intervals. Rotational assignments on the other hand involve the relocation of an employee from their home location to take up a post in a foreign location for a short period of time followed by a period of time off in their home country (Welch \& Worm, 2006). Commuter assignments are being used more frequently than they have been in the past (Deloitte, 2013a; KPMG, 2015b). A survey of MNEs indicated a $42 \%$ increase in this assignment type over a seven-year period (KPMG, 2015b). There is little available evidence on the actual extent to which rotational assignments are used, however survey research indicates that in $201365 \%$ of MNEs expected their number of rotational assignments to increase over the following five years (Deloitte, 2013b).

There has been relatively limited empirical work on commuter and rotational assignments. However, empirical research does indicate that like assignees who undertake other alternative forms of IA, assignees on rotational assignments are confronted by factors which affect their family lives. Such factors include time spent away from home, unpredictable work schedules, and limited control over work schedules (Baker \& Ciuk, 2015; Danehl, 2015). Compliance to tax, immigration and other legal requirements are major challenges involved in managing international commuters for global mobility professionals (Deloitte, 2013a). One interesting insight has been the role of agency in negotiating international roles which fit better with individual's personal circumstance (Kirk, 2015). One interviewee in Kirk's (2015) study, described by the author as 'very senior' outlined how he leveraged his seniority combined with significant previous international experience to turn down a long-term assignment in the USA and instead negotiated 
a commuter assignment from Switzerland to the US on a monthly basis. This points to the perceived preference for commuter type assignments for some individuals.

All in all, this review of research around alternative forms of international assignments confirms that despite their growing prevalence, research evidence remains limited. One could argue that the research agenda has been dominated by self-initiated expatriates (SIEs) at the expense of these alternative forms of corporate assignments. SIEs has become a key research theme in international HRM although out of the scope of the current review. One of the key challenges of this literature base is a lack of clarity around the conceptual boundaries of SIEs. In other words, the difference between a migrant, a SIE and other forms of personal mobility remain for the most part poorly understood (cf. Andresen et al, 2014; Baruch et al, 2016; McNulty and Brewster, 2017). Thus, while SIEs are clearly an important means through which people relocate internationally for work, we call for an increased focus on alternative forms of international assignments as defined above. Our review suggests that the extant focus of research on alternative forms of assignments has largely been on understanding the personal conflicts that emerge in the context of the personal separation of these assignments. This is clearly an important focus, however, this broader area is one where the potential for further research is ample.

The first area which we identify as requiring further study is around the unique demands of alternative forms of international assignments. As Star's (2009) research demonstrated while short-term assignments did avoid some of the problems traditionally associated with long-term assignments, they also create new ones. The failure to effectively manage this may be owing to a poor understanding of the nature of the international work itself. This is important as the typical job responsibilities and demands of international work continue to be poorly understood (Kraimer et al, 2016). When the variations of alternative forms of international work are added to the equation the complexity is evident. Nonetheless, common challenges of international work have 
been identified as international travel requirements, cognitive flexibility, and non-work disruptions (Shaffer et al, 2012). While this list is not exclusive it is indicative. It is likely that the relative importance of these challenges may vary depending on the type of mobility and it is likely that a more differentiated approach to managing these forms of mobility is called for.

We also call for an increased focus on more performative aspects of alternative forms of international assignments. This suggests a focus on dependent variables beyond personal adjustment and physical and emotional impact on personal and family life. For example, how effective are these alternative forms of international assignments on delivering on the assignment objectives. Thus, similar to traditional long-term IAs, less lengthy alternatives can be used for developing employees (Tahvanainen et al., 2005). However, we have a poor understanding of the developmental impact of shorter-term assignments, IBT, commuter, or rotational assignments. Could they be more beneficial for the development of high potential employees owing to the fact that they provide employees with more frequent and varied international experience? For instance, a high potential employee may undertake just one traditional long-term IA in one location over a three-year period, compared to multiple short-term assignments in several different locations over the same period. Further, the opportunity for more frequent international experiences increases in the case of IBTs, commuter, and rotational assignments because of their shorter durations. In the context of traditional international assignments empirical research has confirmed that assignments premised on management development foster personal change and role innovation as the assignee adapts his or her frame of reference in acclimatizing to the new environment (Shay \& Baack, 2004). It would be instructive to explore if how the role is framed impacts on the development potential of alternative forms of international assignments. Future research should explore how the emerging political climate and the challenges to international mobility outlined above impact on the usage and experience of alternative forms of international assignments for individuals and organisations alike. 


\section{Beyond Employees in Global Staffing ${ }^{1}$}

The final theme in our review concerns the emerging importance of non-employees in global staffing. There is also increasing recognition that the nature of business and employment are changing with a resultant impact on how organisations compete and deliver on their strategy and mission (Boudreau, Jesuthasan and Creelman, 2015). The trends that that we foreshadowed in our introduction are significant in creating a context where these emerging alternatives become viable global staffing options.

While a-typical employment arrangements were historically cost driven, and hence their value was premised on a cost minimization strategy, the talent landscape has altered significantly over recent years. Cost is arguably no longer the prime driver of contractor and other a-typical employment relationships. Rather firms are using global talent markets to respond in a more agile and flexible way to the demands of an increasingly volatile environment. Indeed, recent research confirms that the assumptions that "temporary workers reduce labor costs" and "temporary workers are cheaper than independent contractors" are open to question (Fisher and Connelly, 2017). Similarly, Chadwick and Flinchbaugh (2013) found that a high proportion of part-time workers in an organization, often seen as a means of generating employment flexibility and cost containment by organizations, is negatively related to firm performance. Thus, the longer-term impacts of such contingent employment relationships require careful consideration.

The shift to a contingent workforce is driven by a number of key trends. First given the evolving nature of the business environment where the pace of change continues to increase, business

\footnotetext{
${ }^{1}$ The discussion in this section draws insights from Collings, D.G., McDonnell, A. and McMackin, J. (2017).
} 
cycles have shortened and technological advances have made collaboration beyond organisational and national boundaries easier. Indeed, Boudreau and colleagues (2015) have argued that as environments become increasingly volatile and uncertain ("high-velocity), organizations have had to look at alternative staffing arrangement such as outsourcing, crowdsourcing, using independent contractors or talent platforms, professional employer organizations, and even borrowing employees from other firms. A flexible workforce is seen as a prerequisite for successfully competing on a global scale.

For example, drawing on contractors as a flexible workforce facilitates access to highly capable talent that may not be available in the local labour market. Bidwell and Briscoe (2009) found that many contractors are highly experienced and skilled highlighting the potential capability available in this cohort. Furthermore, key capabilities which may be required for a particular project and may not be available in-house become available through such relationships. From an organisational perspective, this provides agility in meeting project requirements in a timely manner without the time constraints of the recruitment cycle. Indeed, the use of contractors, where appropriate, allows organisations to respond with agility and flexibility in scaling staffing levels to meet shifts in increasingly volatile markets. It also facilitates scaling as organisations grow and expand. From a global staffing perspective, the labour market becomes increasingly global with potential access to expert talent globally.

Additionally, there is little doubt that a person who has performed a task on an ongoing basis is likely to be far more productive than a worker who is new to the problem (see O'Boyle and Kroska, 2017). As Bill Gates' oft cited quote highlights “A great lathe operator commands several times the wage of an average lathe operator, but a great writer of software code is worth 10,000 times the price of an average software writer'. This reinforces the potential value of having a highly 
skilled and experienced contractor perform a task as opposed to a non-expert employee. This solution not only addresses the talent issue but equally should reduce cost, avoid an unnecessary permanent headcount for a specialist skill requirement, speed up the process through efficiency accessing the skills quickly and in completing the task.

A further key constraint of traditional talent models is that experts with specialist skills end up doing work that are relatively mundane and detract them from higher value roles and work. In this regard, contractors and other offshoring alternatives offer great potential for relieving key talent from these standard and mundane tasks and expanding the talent-pool with less experienced incumbents who would be well capable of performing this work at a lower cost (Boudreau et al, 2015). Given we know that individuals with limited career experience are likely to contract as they build their career (Bidwell and Briscoe, 2009), there is likely to be good availability of competent talent with the capability to perform this routine work on the global labour market. This approach clearly represents a much more strategic approach to workforce planning ensuring the key technical experts are freed up to spend more time on roles that they are uniquely placed to undertake and that are much more central to firm strategy. From a global staffing perspective, it also aligns with a more strategic approach with a differentiated approach for more critical or pivotal roles.

In responding to this challenge, MNEs need to seek out expert talent in ways that fall outside the traditional employment model. The traditional talent model of a sole reliance on full time employees, which it is argued was a response to the needs of a particular historical period, is under question (Cappelli and Keller, 2012; Younger and Smallwood, 2016). Indeed, preliminary research evidence indicates that the use of outsourcing and contingent work has also benefited certain employees (see Bidwell et al., 2013) and not only employers. 
Cascio and Boudreau (2016) point to potential novel forms of non-employment talent platforms which are likely to become a key part of MNE's global staffing systems. These include talent alliances, talent trading, tours of duty, freelancers, in addition to more traditional options such as outsourcing, temporary employment and contractors. Indeed, developing conceptual clarity around these different forms of alternative work arrangements represents an important step in better understating the issues around them (Cappelli and Keller, 2012). Given the early stage in the emergence of these relationships, important questions around risk and compliance in these contingent workforces, and how to effectively manage and lead in these contexts, require further elaboration.

While it is difficult to have an accurate sense of the scale of these a-typical arrangements, European data suggest that approximately 32 per cent of workers had some sort of a contingent work arrangement (Maselli, Lenaerts and Beblavy, 2016). Other estimates are even higher ranging up to 50 per cent (Younger, Patterson and Younger, 2015). Some 7.4 per cent of the US population constitute independent contractors alone (Bidwell and Briscoe, 2009). UK data suggests that the freelance workforce there has expanded from 1.04 million workers in 1992 to 1.91 million in 2015 (Kitching, 2015). Hence there is a significant pool of labour available across the globe. This research confirms that individuals often pursue contractor type arrangements by choice bringing highly skilled and experienced contractors with in-demand skills into the labour market (Bidwell and Briscoe, 2009). Hence, from an organisational perspective these alternative talent platforms provide access to high quality talent globally, maximise the deployment of core employees to focus on key tasks, provide access to talent and skills when scaling, facilitate agility in accessing skills as required, and also help costs. We know far less about how to engage this talent and how to maximise their contribution to sustainable organisation performance (c.f. Boudreau, Jesuthasan and Creelman, 2015; Younger and Smallwood, 2016). This creates a 
number of challenges for global staffing and will require HR professionals to manage a much more complex range of global staffing arrangements. One challenge is that our understating of human resource management, organizational behavior and global staffing is generally based on studies on employees in large organisations (Cappelli and Keller, 2012). As John Boudreau and his colleagues summarise in their recent book Lead the Work,

the end of job security loosened some fundamental rigging that held the organization together. The organizational boundaries had been breeched, and as a result, people left more readily and work was sent outside the company without much fanfare.

Hence it is not just surprising but worrying that new forms of work in organization have not received more attention (c.f. Barley, Becky and Milliken, 2017). One key question relates to the identity of these non-employees which is no longer likely to be tied to an employing organization (Barley et al, 2017). This is significant given that forms of organization, institutional structures of employment and the experiences of workers in employment have traditionally been intrinsically linked to what they do, how they do it and social order (Barley et al, 2017). In the context of global staffing this is amplified by the multiple identities that individuals often struggle to reconcile. In this context individuals located at subsidiary units traditionally could identify with two different units, the subsidiary and the HQ (Ashforth, Harrison and Corley, 2008; Reade, 2001; Vora and Kostova, 2007). It has been argued that managing this "dual organizational identification", through integrating these dual organizational identities is as an important antecedent of individuals performing more effectively in complex organizational situations (Vora and Kostova, 2007). However, questions of how identity play out in these novel work arrangements in the MNE is an important question for study. 
Overall the performative consequences of contingent work are as yet poorly understood. While some research points to some positive performative impacts of non-standard work arrangements, the literature is inconclusive. For example, Lepak, Takeuchi, and Snell (2003) found that firms relying more heavily on external contract workers exhibited higher profitability. While, based on data from annual reports, Nayar and Willinger (2001) found that companies with a higher percentage of nonstandard workers reported higher profits and increased stock returns. Conversely, more recent research confirms that high percentages of contingent labour many be costlier (Fisher and Connelly, 2017) and indeed impede the longer-term performance of the organization (Chadwick and Flinchbaugh, 2013). What seems clear is that a more nuanced understanding of a-typical work arrangements in the global context is required which provides an understanding of how different forms of these agreements yield value for organizations and individuals alike. (c.f. Cappelli and Keller, 2013)

At a macro level these challenges are also amplified by the fact that virtually all organizational systems and polices combined with legislation and public policy is premised on a traditional employment model (Cascio and Boudreau, 2016). Given the significant changes to national frameworks around migration and work visas in light of the Trump Administration in the US and the BREXIT negotiations in the UK this is a context which is in great flux and which is likely to evolve significantly over the coming years.

\section{Conclusions}

There is little doubt that the importance of global staffing to MNE effectiveness and performance has not diminished. Further, despite the posited decline of organizational careers and corporate expatriation it is clear that global staffing arrangements continue to draw significantly on traditional expatriate assignments, short-term assignments, IBT, commuter and rotational assignments. 
While the topography of global staffing may be more complex and varied than in the past the organizational context of global staffing remains significant. One worrying trend evidenced in the current review is the relatively limited research focus on alternative forms of global mobility. It seems that academic work has become overly focused on self-initiated expatriates to the determent of alternative forms of international assignments. This may be owing to the fact that although messy to collect data on SIEs, it generally does not require an MNE to sign off on research access making access to these individuals relatively easier. However, while clearly an important area for research there is also significant potential for research on alternatives to the traditional international assignment.

The review also pointed to the importance of further research at the interface of global staffing and global talent management. Given the ongoing challenges which MNEs face in attracting and retaining key talent, global staffing remains a significant concern for research and practice. Indeed, building better insights into this integration represents a key opportunity for global staffing research.

Across all three of the critical areas considered in our review, a focus on dependent variables beyond personal adjustment and physical and emotional impact on personal and family life would greatly advance the literature. While clearly the former are important, in considering the strategic impact of global staffing arrangements and advancing the conversation and practice around ROI a focus on performance is key. For example, how effective are alternative forms of international assignments on delivering on the assignment objectives; how does the quality and quantity of non-employees compare to employees; what challenges around risk, compliance and quality emerge in relation to the latter group. Researching, dependant variables such as these are key in advancing our understanding of these emerging phenomena. 
Finally, the exogenous influences on global staffing are in a state of flux. For example, how changes in rules on migration play out in developed economies and how various political, legislative and cultural changes impact on global staffing are important and timely questions. Equally how will such changes impact on the location decisions of MNE operations. Finally, the increasing importance of non-employees on global staffing in the MNE will be interesting to explore.

Global staffing remains a vibrant and dynamic topic in the international HRM literature. Although far from exhaustive, we hope the current review will stimulate further research in this important area. 


\section{REFERENCES}

Adler, N. J. (1981). Re-entry: Managing cross-cultural transitions. Group \& Organization Management, 6, 341-356.

Allen, K. (2017). UK firms struggle to find employees - even before Brexit bites, The Guardian, online, downloaded from, https://www.theguardian.com/money/2017/may/09/uk-firms-struggleto-find-employees-even-before-brexit-bites?CMP=twt gu, last accessed, 26 $6^{\text {th }}$ June 2017.

Al Ariss, A., Cascio, W. F., \& Paauwe, J. (2014). Talent management: Current theories and future research directions. Journal of World Business, 49, 173-179.

Andresen, M., Bergdolt, F., Margenfeld, J. and Dickmann, M. (2014). Addressing international mobility confusion - Developing definitions and differentiations for self-initiated \& assigned expatriates as well as migrants. The International Journal of Human Resource Management. 25 (16): 2295-2318.

Ashforth, B. E., Harrison, S. H., \& Corley, K. G. 2008. Identification in organizations: An examination of four fundamental questions. Journal of Management, 34, 325-374.

Baker, C., \& Ciuk, S. (2015). Keeping the family side ticking along: An exploratory study of the work-family interface in the experiences of rotational assignees and frequent business travellers. Journal of Global Mobility, 3, 137-154.

Barley, S. R., Bechky, B. A., \& Milliken, F. J. (2017). The Changing Nature of Work: Careers, Identities, and Work Lives in the 21st Century. Academy of Management Discoveries, 3(2), 111115. 
Baruch, Y., Dickmann, M., Altman, Y., \& Bournois, F. (2013). Exploring international work: Types and dimensions of global careers. The International Journal of Human Resource Management, 24, 2369-2393.

Baruch, Y., Altman, Y., \& Tung, R. L. (2016). Career mobility in a global era: advances in managing expatriation and repatriation. The Academy of Management Annals, 10(1), 841-889.

Bidwell, M. and Briscoe, F. (2009). Who Contracts? Determinants of the decision to work as an independent contractor among information technology workers. Academy of Management Journal, 52, pp. 1148-1168

Black, J. S., \& Gregersen, H. B. (1999). The right way to manage expats. Harvard Business Review, 77, 52-59.

Bolino, M. C., Klotz, A. C., \& Turnley, W. H. (2017). The implications of turning down an international assignment: a psychological contracts perspective. The International Journal of Human Resource Management, 28(13), 1816-1841.

Borman, W.C. and Silzer, R.F. (2017).The Potential for Leadership, In D.G. Collings, K. Mellahi and W.F. Cacsio (eds) The Oxford Handbook of Talent Management, Oxford, OUP.

Boudreau, J. W., Jesuthasan, R., \& Creelman, D. (2015). Lead the work: Navigating a world beyond employment. John Wiley \& Sons.

Bozkurt, Ö., \& Mohr, A. T. (2011). Forms of cross-border mobility and social capital in multinational enterprises. Human Resource Management Journal, 21(2), 138-155. 
Bird, A., \& Mendenhall, M. E. (2016). From cross-cultural management to global leadership: Evolution and adaptation. Journal of World Business, 51(1), 115-126.

Brookfield Global Relocation Services (2015), Global relocation trends survey. Woodbridge, Illinois: Brookfield Global Relocation Services.

Brookfield Global Relocation Services. (2016). Beyond the basics: expanding assistance to international EBTs. Woodridge, Illinois: Brookfield Global Relocation Services.

Caligiuri, P., \& Bonache, J. (2016). Evolving and enduring challenges in global mobility. Journal of World Business, 51(1), 127-141.

Caligiuri, P.M. and Dragoni, L. (2015). Global Leadership Development. In D.G. Collings, G.T. Wood and P.M. Caligiuri (eds) Routledge Companion to International Human Resource Management, New York, Routledge.

Cappelli, P., \& Keller, JR (2012). Classifying work in the new economy. Academy of Management Review, 38(4), 575-596

Cascio, W. F., \& Boudreau, J. W. (2016). The search for global competence: From international HR to talent management. Journal of World Business, 51(1), 103-114.

Carpenter, M. A., \& Fredrickson, J. W. (2001). Top management teams, global strategic posture, and the moderating role of uncertainty. Academy of Management Journal, 44, 533-545. 
Carpenter, M. A., Sanders, W. G., \& Gregersen, H. B. (2001). Bundling human capital with organizational context: The impact of international assignment experience on multinational firm performance and CEO pay. Academy of Management Journal, 44, 493-511.

Cerdin, J. L., \& Brewster, C. (2014). Talent management and expatriation: Bridging two streams of research and practice. Journal of World Business, 49, 245-252.

Chadwick, C., \& Flinchbaugh, C. (2013). The Effects of Part-Time Workers on Establishment Financial Performance. Journal of Management, doi. 0149206313511116.

Collings, D. G. (2014). Integrating global mobility and global talent management: Exploring the challenges and strategic opportunities. Journal of World Business, 49, 253-261.

Collings, D.G., McDonnell, A. and McMackin, J. (2017) Prospects for Talent Management, in P. Sparrow and C. Cooper (Eds) A Research Agenda for Human Resource Management - HR strategy, structure, and architecture, Cheltenham, Edward Elgar.

Collings, D.G. \& Isichei, M. (2017). Global Talent Management: What Does It Mean for Expatriates? in Y. McNulty \& J. Selmer (Eds.). Research Handbook of Expatriates. Cheltenham, UK: Edward Elgar.

Collings, D. G., Scullion, H., \& Dowling, P. J. (2009). Global staffing: A review and thematic research agenda. The International Journal of Human Resource Management, 20(6), 1253-1272. 
Collings, D. G., Scullion, H., \& Morley, M. J. (2007). Changing patterns of global staffing in the multinational enterprise: Challenges to the conventional expatriate assignment and emerging alternatives. Journal of World Business, 42, 198-213.

Copeland, A. (2009). Voices from home: The personal and family side of international short-term assignments. Brookline, MA: The Interchange Institute.

Crowley-Henry, M., \& Heaslip, G. (2014). Short-term international assignments. Military perspectives and implications for international human resource management. European Management Journal, 32, 752-760.

Danehl, J. (2015). It's time for rotators to come out of the shadows. London: Crown World Mobility. Deloitte. (2013a). Commuter survey report: Business or personal? Current trends in managing commuter assignments. London, UK: Deloitte.

Deloitte. (2013b). Oil \& Gas industry rotator assignment panel discussion: In high demand and on the rise. Deloitte.

Dickmann, M. (2015). RES Forum annual report: Strategic global mobility and the talent management conundrum. London: RES Forum.

Dixon, L. (2017) Tighter Immigration Policy Pushes Firms to Open Foreign Satellite Offices, Talent Economy, online, downloaded from, http://www.talenteconomy.io/2017/06/19/tighterimmigration-policy-pushes-firms-open-foreign-satellite-offices/\#.WUlkmEY5Yvo.twitter last accessed $26^{\text {th }}$ June 2017. 
Doherty, N., C. Brewster, V. Suutari, and M. Dickmann (2008). Repatriation: the end or the middle? in Michael Dickmann, Chris Brewster and Paul Sparrow (Eds.), International HRM Contemporary Issues in Europe, London: Routledge, pp. 174-191.

Doherty, N. and Dickmann, M. (2012). Measuring the return on investment in international assignments: an action research approach. The International Journal of Human Resource Management, Vol 23(16): 3434-3454.

Dowling, P. J., Festing, M. and Engle, A. D. (2008). International Human Resource Management (5th edn). London: Thompson.

Evans, P., Pucik, V., \& Barsoux, J. L. (2002). The global challenge. McGraw-Hill Publishing Company.

Farndale, E., Pai, A., Sparrow, P., \& Scullion, H. (2014). Balancing individual and organizational goals in global talent management: A mutual-benefits perspective. Journal of World Business, 49, 204-214.

Farndale, E., Scullion, H., \& Sparrow, P. 2010. The role of the corporate HR function in global talent management. Journal of World Business, 45: 161-168.

Fisher, S., \& Connelly, C. (2017). Lower Cost or Just Lower Value? Modeling the Organizational Costs and Benefits of Contingent Work. Academy of Management Discoveries, 3: 2, 165-186.

Gong, Y. (2003). Subsidiary staffing in multinational enterprises: Agency, resources, and performance. Academy of Management Journal, 46(6), 728-739. 
Harris, H., \& Brewster, C. (1999). The coffee-machine system: how international selection really works. International Journal of Human Resource Management, 10, 488-500.

Haslberger, A., \& Brewster, C. (2009). Capital gains: Expatriate adjustment and the psychological contract in international careers. Human Resource Management, 48, 379-397.

Harvey, M. G. (1989). Repatriation of corporate executives: An empirical study. Journal of International Business Studies, 20, 131-144.

Harvey, M., \& Novicevic, M. M. (2006), 'The Evolution from Repatriation of Managers in MNE's to 'Patriation" in Global Organizations,' in Handbook of Research in International Human Resource Management, eds. G.K. Stahl and I. Bjorkman, Cheltenham: Edgar Elgar

Kirk, S. (2016). Career capital in global Kaleidoscope Careers: the role of HRM. The International Journal of Human Resource Management, 27(6), 681-697.

Kitching, J. (2015). Tracking UK freelance workforce trends 1992-2015. International Review of Entrepreneurship, 13(1), 21-34.

KPMG. (2015a). International assignment policies and practices survey. Geneva: KPMG.

KPMG. (2015b). International assignment policies and practices survey - Swiss headquartered companies. Geneva: KPMG. 
Kraimer, M., Bolino, M., \& Mead, B. (2016). Themes in expatriate and repatriate research over four decades: What do we know and what do we still need to learn?. Annual Review of Organizational Psychology and Organizational Behavior, 3, 83-109.

Lazarova, M. (2015). Taking stock of repatriation research. in David G. Collings, Geoffrey T. Wood and Paula M. Caligiuri (Eds.), The Routledge Companion to International Human Resource Management, New York, NY: Routledge, pp. 378-398.

Lazarova, M. B., \& Cerdin, J. L. (2007). Revisiting repatriation concerns: Organizational support versus career and contextual influences. Journal of International Business Studies, 38(3), 404429.

Lepak, D. P., Takeuchi, R., \& Snell, S. A. (2003). Employment flexibility and firm performance: Examining the interaction effects of employment mode, environmental dynamism, and technological intensity. Journal of Management, 29(5), 681-703.

Lepak, D. P., \& Snell, S. A. (1999). The human resource architecture: Toward a theory of human capital allocation and development. Academy of Management Review, 24(1), 31-48.

Mahmud, A. (2017). Looking beyond H-1B visas to attract technical talent. Harvard Business Review, online, downloaded from https://hbr.org/2017/06/looking-beyond-h-1b-visas-to-find-tech-

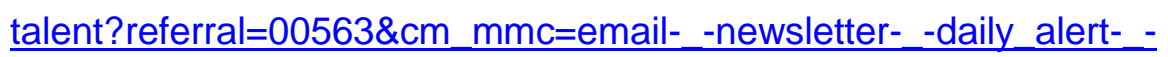
alert date\&utm source=newsletter daily alert\&utm medium=email\&utm campaign=alert date \&spMailingID=17510947\&spUserID=NTE4ODU0NDgwNjUS1\&spJobID=1041693419\&spReport Id=MTAOMTY5MzQxOQS2 last accessed 26 $6^{\text {th }}$ June 2017. 
Mäkelä, L., Bergbom, B., Saarenpää, K., \& Suutari, V. (2015). Work-family conflict faced by international business travellers. Journal of Global Mobility, 3, 155-168.

Mäkelä, L., \& Kinnunen, U. (2016). International business travelers' psychological well-being: the role of supportive HR practices. The International Journal of Human Resource Management, 122. DOI $10.1080 / 09585192.2016 .1194872$

Mäkelä, L., Känsälä, M. \& Suutari, V. (2011). The role of expatriates' spouses among dual career couples. Cross Cultural Management, 18: 185-197.

Mäkelä, L., Saarenpää, K., \& McNulty, Y. (2017). Flexpatriates, short-term assignees and international commuters. In Yvonne McNulty and Jan Selmer (eds.), Research Handbook of Expatriates. Cheltenham: Edward Elgar.

Marler, J. H., \& Boudreau, J. W. (2017). An evidence-based review of HR Analytics. The International Journal of Human Resource Management, 28(1), 3-26.

Maselli, I., Lenaerts, K., \& Beblavý, M. (2016). Five things we need to know about the collaborative economy. CEPS Essay, (21).

Mayerhofer, H., Hartmann, L. C., \& Herbert, A. (2004). Career management issues for flexpatriate international staff. Thunderbird International Business Review, 46, 647-666.

Mayerhofer, H., Hartmann, L. C., Michelitsch-Riedl, G., \& Kollinger, I. (2004). Flexpatriate assignments: a neglected issue in global staffing. The International Journal of Human Resource Management, 15(8), 1371-1389. 
Mayrhofer, W. Reichel, A. \& Sparrow, P. R. (2012) Alternative forms of international working. In G. Stahl, I. Björkman \& S.Morris (eds.) Handbook of Research into International HRM 2nd Edition. London: Edward Elgar. pp. 300-327.

McDonnell, A., Scullion, H., \& Lavelle, J. (2013). Managing human resources in large international organizations. In G. Sarikades \& C. L. Cooper (Eds.), How can HR drive growth (pp. 4-25). Cheltenham, UK: Edward Elgar.

McNulty, Y., \& Brewster, C. (2017). The concept of business expatriates in Y. McNulty \& J. Selmer (Eds.). Research Handbook of Expatriates. Cheltenham, UK: Edward Elgar.

McNulty, Y., \& De Cieri, H. (2016). Linking global mobility and global talent management: the role of ROI. Employee Relations, 38, 8-30.

McNulty, Y., De Cieri, H., \& Hutchings, K. (2009). Do global firms measure expatriate return on investment? An empirical examination of measures, barriers and variables influencing global staffing practices. The International Journal of Human Resource Management, 20(6), 1309-1326.

Meyskens, M., Von Glinow, M. A., Werther, Jr, W. B., \& Clarke, L. (2009). The paradox of international talent: Alternative forms of international assignments. The International Journal of Human Resource Management, 20, 1439-1450.

Mellahi, K., \& D. G., Collings. (2010). The barriers to effective global talent management: The example of corporate elites in MNEs. Journal of World Business, 45(2), 143-149. 
Morgan, J. (2014). The future of work: Attract new talent, build better leaders, and create a competitive organization. John Wiley \& Sons.

Nayar, N. N., \& Willinger, G. (2001). Financial implications of the decision to increase reliance on contingent labor. Decision Sciences, 32(4), 661-682.

Nijs, S., Gallardo-Gallardo, E., Dries, N., \& Sels, L. (2014). A multidisciplinary review into the definition, operationalization, and measurement of talent. Journal of World Business, 49(2), 180191.

O'Boyle, E.H. \& Kroska, S. 2017. Star employees in D.G. Collings, K. Mellahi \& W.F. Cascio (Eds.) Oxford Handbook of Talent Management, Oxford, OUP Press.

Osland, J.S. (1995). The Adventure of Working Abroad. Jossey-Bass, San Francisco PricewaterhouseCoopers. (2005). International assignments: Global policy and practice, Key trends 2005. PricewaterhouseCoopers.

Pate, J., \& Scullion, H. (2016). The flexpatriate psychological contract: a literature review and future research agenda. The International Journal of Human Resource Management, 1-24. DOI: 10.1080/09585192.2016.1244098

Pate, J., \& Scullion, H. (2009). The changing nature of the traditional expatriate psychological contract. Employee Relations, 32, 56-73. 
Phillips, J. M., Gully, S. M., McCarthy, J. E., Castellano, W. G. and Kim, M. S. (2014), Recruiting Global Travelers: The Role of Global Travel Recruitment Messages and Individual Differences in Perceived Fit, Attraction, and Job Pursuit Intentions. Personnel Psychology, 67: 153-201.

PWC (2017). CEO Success Study, accessed online https://www.strategyand.pwc.com/ceosuccess2016/incomingclass2016, last accessed $26^{\text {th }}$ June 2017.

PWC. (2014). Moving People With Purpose: Modern Mobility Survey. PWC.

Reade, C. 2001. Dual identification in multinational corporations: Local managers and their psychological attachment to the subsidiary versus the global organization. International Journal of Human Resource Management, 12, 405-424.

Santa Fe Relocation Services. (2017). Embedding Global Mobility in Business Strategy Report.

Santa Fe Relocation Services. (2016). Embedding Global Mobility in Business Strategy Report.

Schuler, R. S., Dowling, P. J., \& De Cieri, H. (1993). An integrative framework of strategic international human resource management. Journal of Management, 19(2), 419-459.

Scullion, H. and Collings, D.G. (2006) Global Staffing, London, Routledge.

Scullion, H., Collings, D. G., \& Caligiuri, P. (2010). Global talent management. Journal of World Business, 45, 105-108. 
Scullion, H., Collings, D. G., \& Gunnigle, P. (2007). International human resource management in the 21st century: emerging themes and contemporary debates. Human Resource Management journal, 17, 309-319.

Scullion, H., \& Starkey, K. (2000). In search of the changing role of the corporate human resource function in the international firm. International Journal of Human Resource Management, 11(6), 1061-1081.

Shaffer, M. A., Kraimer, M. L., Chen, Y. P., \& Bolino, M. C. (2012). Choices, challenges, and career consequences of global work experiences: A review and future agenda. Journal of Management, 38, 1282-1327.

Shay, J. P., \& Baack, S. A. (2004). Expatriate assignment, adjustment and effectiveness: An empirical examination of the big picture. Journal of International Business Studies, 35(3), 216232.

Shen, Y., \& Hall, D. T. T. (2009). When expatriates explore other options: Retaining talent through greater job embeddedness and repatriation adjustment. Human Resource Management, 48, 793816.

Silzer, R.F. \& Boreman, W.C. (2017) The Potential for Leadership, in D.G. Collings, K. Mellahi \& W.F. Cascio (Eds.) Oxford Handbook of Talent Management, Oxford, OUP Press.

Sparrow, P. (2012). Globalising the international mobility function: The role of emerging markets, flexibility and strategic delivery models. The International Journal of Human Resource Management, 23(12), 2404-2427. 
Stahl, G., Björkman, I., Farndale, E., Morris, S. S., Paauwe, J., Stiles, P., Traveor, J., \& Wright, P. (2012). Six principles of effective global talent management. Sloan Management Review, 53, 25-42.

Star, T.L. (2009). Repatriation and short-term assignments: An exploration into expectations, change and dilemmas. International Journal of Human Resource Management. 29: 2, 286-300.

Starr, T. L., \& Currie, G. (2009). 'Out of sight but still in the picture': short-term international assignments and the influential role of family. The International Journal of Human Resource Management, 20, 1421-1438.

Suutari, V., \& Brewster, C. (2001). Making their own way: International experience through selfinitiated foreign assignments. Journal of World Business, 35, 417-436.

Tahvanainen, M., Welch, D., \& Worm, V. (2005). Implications of short-term international assignments. European Management Journal, 23, 663-673.

Tarique, I., \& Schuler, R. S. (2010). Global talent management: Literature review, integrative framework, and suggestions for further research. Journal of World Business, 45, 122-133.

Vora, D., \& Kostova, T. (2007). A model of dual organizational identification in the context of the multinational enterprise. Journal of Organizational Behavior, 28(3), 327-350. 
Welch, D. E., Welch, L. S., \& Worm, V. (2007). The international business traveller: A neglected but strategic human resource. The International Journal of Human Resource Management, 18, 173-183.

Welch, D. E., \& Worm, V. (2006). International business travellers: A challenge for IHRM. In G. Stahl, \& I. Björkman (Eds.), Handbook of Research in International Human Resource Management: 283-301. Cheltenham, UK: Edward Elgar Publishing.

Westman, M., \& Etzion, D. (1995). Crossover of stress, strain and resources from one spouse to another. Journal of Organizational Behavior, 16, 169-181.

Westman, M., Etzion, D., \& Chen, S. (2009). Crossover of positive experiences from business travelers to their spouses. Journal of Managerial Psychology, 24, 269-284.

You, J., Bohannon, J. and Stone, R. (2017) Raising the drawbridge. Science. 355, 6328, pp. 896.

Younger, J. \& Smallwood, N. (2016). Aligning Your Organization with an Agile Workforce. Harvard Business Review, online, downloaded from https://hbr.org/2016/02/aligning-your-organizationwith-an-agile-workforce last accessed $9^{\text {th }}$ September 2017 


\begin{tabular}{|c|c|c|c|c|c|}
\hline & $\begin{array}{l}\text { Defining } \\
\text { Characteristics }\end{array}$ & $\begin{array}{l}\text { Extent of Use in } \\
\text { MNES }\end{array}$ & $\begin{array}{l}\text { Development in } \\
\text { Academic } \\
\text { Literature }\end{array}$ & $\begin{array}{l}\text { Organisational } \\
\text { Outcomes }\end{array}$ & $\begin{array}{l}\text { Individual } \\
\text { Outcomes }\end{array}$ \\
\hline $\begin{array}{l}\text { Short-Term } \\
\text { Assignments }\end{array}$ & $\begin{array}{l}\text { - Typically 1-12 } \\
\text { months long. } \\
\text { - Does not involve } \\
\text { relocation of } \\
\text { assignee's family. } \\
\text { - Benefits and } \\
\text { salary } \\
\text { administered in } \\
\text { home country. }\end{array}$ & $\begin{array}{l}\text { - Most popular } \\
\text { alternative form } \\
\text { of IA. }\end{array}$ & $\begin{array}{l}\text { - Slower than } \\
\text { expected given } \\
\text { extent of adoption } \\
\text { in practice. }\end{array}$ & $\begin{array}{l}\text { - Increase in social } \\
\text { capital across an } \\
\text { MNE's global } \\
\text { network (Bozkurt } \\
\text { and Mohr, 2011). }\end{array}$ & $\begin{array}{l}\text { - Positive } \\
\text { professional } \\
\text { experiences } \\
\text { (Crowley-Henry \& } \\
\text { Heaslip, 2014). } \\
\text { - Potential } \\
\text { negative impacts } \\
\text { spousal } \\
\text { relationships } \\
\text { (Starr and Currie, } \\
\text { 2009). }\end{array}$ \\
\hline $\begin{array}{l}\text { International } \\
\text { Business Travel } \\
\text { (IBT) }\end{array}$ & $\begin{array}{l}\text { - Frequent } \\
\text { international trips } \\
\text { to foreign locations } \\
\text { and subsidiaries } \\
\text { throughout the } \\
\text { duration of } \\
\text { employment. } \\
\text { - Deployed to meet } \\
\text { continuously } \\
\text { evolving needs of } \\
\text { MNE. } \\
\text { - Often deployed } \\
\text { with little prior } \\
\text { notice. }\end{array}$ & $\begin{array}{l}\text { - Steady increase } \\
\text { in use. Up to } 64 \% \\
\text { of MNEs now } \\
\text { formally use IBT } \\
\text { designation } \\
\text { (Santa Fe } \\
\text { Relocation } \\
\text { Services, 2017). }\end{array}$ & $\begin{array}{l}\text { - Some instructive } \\
\text { research exists } \\
\text { but more is } \\
\text { welcomed. }\end{array}$ & $\begin{array}{l}\text { - Sustenance of } \\
\text { social networks } \\
\text { (Bozkurt and } \\
\text { Mohr, 2011). }\end{array}$ & $\begin{array}{l}\text { - Development of } \\
\text { cross-unit social } \\
\text { ties and } \\
\text { consolidation of } \\
\text { existing ties } \\
\text { (Bozkurt and } \\
\text { Mohr, 2011). } \\
\text { - High levels of } \\
\text { stress (Welch, } \\
\text { Welch \& Worm, } \\
\text { 2007). } \\
\text { - Positively related } \\
\text { to work } \\
\text { engagement }\end{array}$ \\
\hline
\end{tabular}




\begin{tabular}{|c|c|c|c|c|c|}
\hline & & & & & $\begin{array}{l}\text { (Vigour) } \\
\text { (Westman, Etzion, } \\
\text { and Chen, 2009). } \\
\text { - Job exhaustion } \\
\text { (Mäkelä and } \\
\text { Kinnunen, 2016). } \\
\text { - Work-family } \\
\text { conflict (Mäkelä } \\
\text { et al., 2015). }\end{array}$ \\
\hline $\begin{array}{l}\text { Commuter and } \\
\text { Rotational } \\
\text { Assignments }\end{array}$ & $\begin{array}{l}\text { Commuter } \\
\text { Assignments } \\
\text { - Travel between } \\
\text { home location and } \\
\text { foreign location on } \\
\text { weekly or bi- } \\
\text { weekly basis. } \\
\text { - Work } \\
\text { responsibilities in } \\
\text { both countries. } \\
\text { Rotational } \\
\text { Assignments } \\
\text { - Short-term } \\
\text { relocation to take } \\
\text { up post in foreign } \\
\text { location followed } \\
\text { by time off in home } \\
\text { location. }\end{array}$ & $\begin{array}{l}\text { Commuter } \\
\text { Assignments } \\
\text { - Used more } \\
\text { frequently than in } \\
\text { the past. 42\% } \\
\text { increase in use } \\
\text { over a 7-year } \\
\text { period (KPMG, } \\
\text { 2015b). } \\
\text { Rotational } \\
\text { Assignments } \\
\text { - Little evidence } \\
\text { on actual extent of } \\
\text { use. In } 201365 \% \\
\text { of MNEs expect } \\
\text { their number of } \\
\text { rotational } \\
\text { assignments to } \\
\text { increase over } 5 \\
\text { years (Deloitte, } \\
\text { 2013b). }\end{array}$ & $\begin{array}{l}\text { - Limited } \\
\text { empirical research } \\
\text { on both commuter } \\
\text { and rotational } \\
\text { assignments. }\end{array}$ & $\begin{array}{l}\frac{\text { Commuter }}{\text { Assignments }} \\
\text { - Legal } \\
\text { consequences } \\
\text { associated with } \\
\text { failure to comply } \\
\text { to tax and } \\
\text { immigration laws } \\
\text { (Deloitte, 2013a). }\end{array}$ & $\begin{array}{l}\underline{\text { Rotational }} \\
\underline{\text { Assignments }} \\
\text { - Strained family } \\
\text { life (Baker \& Ciuk, } \\
\text { 2015; Danehl, } \\
\text { 2015). }\end{array}$ \\
\hline
\end{tabular}


Table 1: Alternative Forms of International Assignments

\footnotetext{
${ }^{\mathrm{i}}$ Although Collings, Scullion, and Morley (2007) also examined global virtual teams, we omitted this alternative to the traditional long-term IA from our discussion. Over the last decade, the literature on global virtual teams has become so extensive in its own right that it is beyond the scope of this paper.
} 